\title{
The Concept of Revolution
}

\section{Dr.Pralhad V Chengte}

Assistant professor of Political Science Government First Grade College Humanabad. India

\begin{abstract}
Revolution as a term implies for a political analyst generally violent political change like a powerful overthrow of a regular form of govt. It has various methods, though the modus operandi differs, it moves towards reform partially in the strict sense of the term.
\end{abstract}

\section{MeAning AND Definition of THE CONCEPT OF REvolution}

As Jacques Ellul observes that revolution and the will of the people should go hand in hand, revolution emphasises the popular will as shown below in his words:

"Revolution and the will of the people are one. At the same time, we cling to the conviction that a state is valid only in so far as it expresses the popular will: state legitimacy virtually resides in popular sovereignty. As the two trends converge, the state does not appear unless founded upon an initial revolutionary act. Its legitimacy is all the firmer if its major concern is spreading revolution and acting in the name of revolution"1.

Whenever there is ruthless exploitation of all kinds, poverty and degradation, revolutions like the violent outburst of French Revolution of 1789 is an expected phenomena.

The contemporary political theory focuses on the politics of power, issues live like manipulations of power, persuation methods, coercion threats all have positive attitude towards revolution and its nature. Revolution covers economic social and cultural spheres of life. A proper definition of revolution covers wide range of implications whether peaceful or violent, either total or violent minor or major show or sudden and likewise.

In political theory revolution refer to a sudden, fundamental trans formation. A change associated with associations and political structure. Ellul also observes:

... 'Revolution' is that it is used interchangeably with other activities like outburst, upheaval, unrest, agitation, rebellion, revolt, coup d'etat and the like which aim at changing the status quo"2. Tells us that revolute is a rebellion against the established political system or the government of a state.

It has also been associated with activities sudden violet out bust of the masses uphearal unrest, a sort of agitation and rebellion which aims at changing the status.

Little refers to revolution as against established authority and likewise refers to revolution as sudden violent change in the political system or the government of a state. Marxist believe that reform as the strategy by the capitalist to defeat the motive of revolution. Ralph Miliband reference to the Marxist charge that : "reformism is just a strategy of the capitalists to check or defeat the purpose of a revolution". This clearly explicates that 'revolution' and reform are two different concepts. Revolution strictly speaking refers to profound change like Martin Luther's Protestant movement against the papal supremacy could also be seen as a religious 'revolution' because it transformed the role of church and the creed of Protestantianism. Barbara Salvert treats revolution in a similar fashion as:

"Although the basic idea of treating revolutions as events initiating widespread social change is probably quite acceptable, there is obvious problem with this definition: it does not indicate how widespread change has to be for a given set of events to be a revolution. Events such as the Chinese Revolution, that introduce changes in everything from the educational system to the land-tenure patterns clearly qualify as revolutions under this definition. But there are many changes of government that have been accompanied by a degree of social change that, while far surpassing 


\section{Dr.Pralhad V Chengte}

routine reform has nevertheless fallen short of the degree of change produced by such events as the French or Russian revolutions. The Bolivian Revolution of 1952 is an example of this: there are many others." 3

Mounier's observation on Revolution is highly commendable since the revolution of the Sharna's carried the same vigour and mass appeal for a radical transformation of society. He reminds that, "By revolution, we mean a combination of rather far-reaching changes intended virtually to erase the real illness of a society that has reached an impasse, rapid enough to prevent those terminal illnesses from spreading their poisonous decay throughout the national body, yet slow enough to allow for the growth of whatever requires time to mature. The result is what counts, not how romantic, or how restrained the language is. It is enough to know that the operation is a major and vital one, bound to meet violent resistance, which in turn provokes counter-violence."4

The revolution of Sharana's like Bertrand de Jouvenels 'Political event phenomena' reflected sociopolitical and cultural implication. It brought about a tremendous reconstruction of socio-political and cultural stability. It aimed like the Neumanns myth of a social, order to shatter the rigidity of ritualistic and dogmatism of religious prescriptions to a simpler and devotional attitude towards man and God.

The political matrix is effected by the new order proclaimed by the revolutionaries and similarly in words of Hannah Arendt it almost assumes the role like that which " is inextricably bound up with the notion that the course of history suddenly begins a new, that an entirely new story never known or told before is about to unfold." 5

A.S.Cohen puts forth the postulates of the nature of revolution as:

1) Alteration of values of myth of the society.

2) Alteration of social structure.

3) Alteration of institution.

4) Change in leadership formation either in personal of the elite or its class composition.

5) Transfer of power by legal or non-legal means.

6) The presence of dominance of violent behavior made evident in the collapse of the regime

Revolution covers not only the field of political activity but also sphere of economics and sociology and with the sharanas it was a revolt of unjust laws of caste rigidity. The role of revolution in social transformation as an event can be best described has an event of history that rarely fulfills its total definition.7

Revolution have figured during various periods of social development around the world and some critics have denounced of this type of non-events. For example the Marxists were not prepared to accept the Indonesian revolution of 1965. It was similarly with the Bangladesh revolution of 1971 as an event of revolution. Ellul provides the application of revolution as, "it is impossible, therefore, to establish an objective and general pattern of revolution or even an adequate definition applicable to all periods. 8

The stages revolution can be generally treated as follows:

1) A liberal revolution of democratic kind where there is democratic triumph over. Dictatorship. This can be noticed in case the 1776 revolution of Americans over the colonial imperial, British powers and also with the 1995 Indonesian people over Dutch imperialists.

2) The great communist revolution of 1917 , which paved the way as a Russian example over countries like china, Vietnam and other socialist countries of the world.

3) A sort of quasi-revolution due to the persistent efforts of important leaders like that of general Charles De Gulle who established a new constitutional system substituting parliamentarism with Bonapartism.

4) Revolution has both limited and unlimited varieties. The 1972 Bhutto regime shift for parliamentary to presidential system and the most wider connotation of the term of the unlimited one with the 'total revolution' of Jayaprakash Narayan who had insight of its influence an social, economic and cultural, educational factors. 
Schwarz attempts at psychological attributes of revolution when he says, "Revolutions begin with this attempted withdrawal from politics of individual (and especially intellectual's) attention, affection and involvement."9

Revolution relies on the process of change, which is the law of nature, the path of progress if the old system or an institution persists with weakness it must crumble or die a sure death.

As Lenin points out in his left-wing communism-An Infantile Disorder asserts; "It is not enough for revolution that the exploited and oppressed masses should understand the impossibility of living in the old way and demand changes, it is essential for revolution that the exploiters should not be able to live and rule in the old way. Only when the 'lower classes' do not want the old way, and when the 'upper classes' cannot carry on in the old ways-only then can revolution triumph." 10 The dynamics of revolution has been the assertion of human freedom for a self realized motive and its expression denoted essence of all human beings. The revolt of the low castes Indians for rights like the movement but under Ambedkar's stress on equality and justice for untouchables carries significant message for emancipation.

Revolution is strengthened due to its leadership impact, they provide concrete shape and future to the movement which certainly would be influencing political economical and social status of life of man. Jayaprakash Narayan sums up the revolutionary vigour as was seen in the sharana context which for a change in socio-religions set-up. Jayaprakash Narayan continues his argument when he refers to revolution under various perspectives:

"We are going through a very deep revolution, a revolution inside the hearts and minds of our young people. One of the most uplifting experiences that I have had in recent years has been the experience of meeting young students. A new spirit seems to move them. It's only Vietnam or the race question, I think something deeper is happening is their hearts. I think they are questioning the values of this civilization, which is sparkling and so attractive to look at. Inside I do not know how sound or hollow it is. Therefore, if these revolutions had been brought about in different ways from those followed so for, may be the outcome of those revolutions would be different." 11

Jayaprakash Narayan further adds that the revolution which Mahatma had in his mind was of double kind which would begin in the minds and hearts of men and resulting in a social revolution in the institutions and outward forms of society. Jayaprakash Narayan holds that revolution should change the values of life by changing their attitudes towards life and towards things like men and nature.

"A revolutionary at this age and time of history where man is landing on the moon should have no lesser ideal than to build a world community of human beings; a real human family. This could be the only revolutionary goal of today. And if this is the goal then all the questions of how aid is to be distributed and percentages of GNP and what machinery and all that, would lose the present meanings and acquire entirely new meanings." 12

Jayaprakash Narayan is highly appreciative of Gramdan movement which aimed at rural co-operation for the reorganization and upliftment of rural India with the focus on self-sufficiency and selfreliance.

If charka served as an instrument of work and worship to Gandhi. Basava's devotion to linga is similar to the Gandhian method of work and devotion. Vinobaji's concept of ideal Gramdan movement which carried great social revolutionary message, it was voluntary renunciation of private property in land then sharing of their labor power. A mutual help system of co-operative workmanship seen among the sharnas for the achievement of desired goals.

The revolution of the sharana's was big blow to the exploitation of man and the revolution has been witnessed in history this promotes an important role for non-violence. Basava's chief importance to individual conscience and Gandhi's stress on voluntarism is very significantly a great instigator of revolutionary strength. Both of them believed that only in individual performance of duty in a prescribed proper manner would be helpful towards solving the problems of society and the nation.

Mahatma Gandhi wanted a new social system which he popularised as Sarvodaya Society. He wanted the change to result from bottom and then to roots of the social foundations. In the words of Jayaprakash Narayan, "he wanted to change the system and the existing social order in India so as to bring about a social revolution. The word 'revolution' in this context only means that society has to 


\section{Dr.Pralhad V Chengte}

change from its roots and its foundations, not merely outwardly but in a fundamental way. He wanted to construct a new society, which he called 'Sarvodaya' Society...." 13

The society which Gandhi had dreamt had its foundation one quality, economic, social and political, negating the exploitative mechanism. The entire power to be transferred into the hands of the people to manage their own affairs more like a self-regulated society. The hard-won freedom for him was not real Swaraj but a condition which was yet to be achieved. Gandhi had constructive approach towards discipline and non-violent on the objectives like the All-India village industries organization. Gandhi relied on the spirit of service organization in achieving the results.

The words of Jayaprakash Naryan still holds significance on the consequences and nature of revolution:

"As a result of the experience of democratic societies in other parts of the world and of democratic government in our own country, I have begun to doubt on the one hand whether social revolution can be brought about by democratic means and, on the other, I reject violence as only half the revolution. The more important half of it is the betrayal of the people."14

The Gandhian autobiography states the efficacy of the power of revolution, which has been unique all over the world narrates his spiritual experience as ... "But I should certainly like to narrate my experiments in the spiritual field which are known only to myself and from which I have derived such power as I possess for working in the political field...what I want to achieve is self-realization... all that I do by way of speaking and writing and all my ventures in the political field are directed to this same end.15

It is the intuitive power of self to associate with the formlessness, common to all men and things, the key to the Gandhi method of revolution for a exploitative imperialistic threat provides solution. This method was applied for a mass revolutionary movement in the social, economic and political sphere, the method of non-violent Satyagraha. It is a great, genuine tradition of revolt, which touched even the deepest roots of social consciousness. Gandhian economics aims at rationality, more spiritual happiness and less worldly pains.

Similarly, the Gandhian method of Trusteeship as a revolutionary device makes a concession to the alienated component of the human personality, through personal ownership which appeals to a personal sense of possession and achievement and taps initiative. Gandhi relied on the establishment of communal unity, abolition of untouchablity, Khadi production, prohibition, development of villages and village industries, village sanitation, basic education, emancipation of women, development of local languages, economic equality, organization of peasants and labor, adivasi welfare, lepers and students welfare.

High morale is as much necessary in the non-violent as in violent combat. The charisma generated by non-violent suffering, gives rise to rival opposition towards authority within the system. This is highly essential to note Rousseau's ideas on revolution. He was a great critic of his society; he put forth his vision of a just society and a happier world. The nineteenth century historian Edgar Quinet who was particularly with the morals and religious aspects of the French revolution wrote that the 'social contract was the revolution book of laws'. The basic idea behind the social contract theory can be best described as follows:

"The Social Contract, which proposed a system for small city-states, declared that the people's sovereignty "could not be exercised by representatives," and that law-making could only be done by an assembly of all the people. In The Government of Poland, however, which deals with a large country, Rousseau does not advocate abolishing the traditional assemblies. Representatives can be elected, provided their mandate is specific and of short duration. It is clear why this work was reprinted several times during the Revolution as an appendix to The Social Contract. And it is also clear why so many orators and political writers of all persuasions borrowed arguments from it. It was proof that Rousseau's thought could be applied to France. 16

Ambedkar's mission was against the injustice penetrated against the Untouchables of the social order which had a long history. It was a struggle for basic human civil rights and human rights.

Though the mass awakening had been carried by Sri Narayan Guru and his followers, Dr. B.R. Ambedkar organised the movement for the untouchables to assert their legal and political rights 
compelled his followers and himself to draw water from the Cowdar tank in 1927. His temple entry movement gained momentum with his mission at Kalaram temple at Nasik. They had to face severe criticism and violence from the caste Hindus. The Manusmriti was burnt in the second phase of the Mahad Satyagraha in December in 1927, at the conference of the Untouchables. The conference declared the following principles:

i) All Hindus have the same social status from birth.

ii) The ultimate aim of political, economic or social changes should be to maintain intact the equal status of all Hindus.

iii) All power is derived from the people.

iv) Every person is entitled to liberty of action and speech as his birthright.

v) Hindus can be deprived of their rights other than their birth rights only by law.

vi) Law is not a command of an individual of a body of individuals. Law is the people's prescription for change. 17

Ambedkar lists following factors which contributed towards the helplessness of the untouchables under the categories:

1. The two groups are unequally matched as far as the numbers are concerned.

2. There is nobody to avenge an injury done to the untouchables.

3. A large majority of the untouchables in the villages are either village servants or landless labourers and they are totally dependent on the caste Hindus for their livelihood.

4. The untouchables have not way of earning a living. They cannot sell milk or vegetables; they cannot take to any trade because all trades are hereditary and their economic dependence upon caste Hindus is complete.

5. The untouchable is also dependent on touchables for purchase of his necessaries of life.

6. The touchables constitute an organised conspiracy to bring about cessation of all economic relationships with untouchables.

7. Physical assault and social boycott are the two major weapons against the untouchables.

8. The untouchables do not own any means of production. They work either as tenants or as labourers.

9. Untouchables do not obtain any protection from the police or justice from the magistrates, as both are drawn from the ranks of the upper castes. They are not only corrupt but prejudiced also, and often more partial than corrupt. While corruption may have some remedies partiality is incurable. It is founded in the social and religious repugnance which is inborn in every upper caste Hindu.

10. The worst aspect of the system is that all this injustice and persecution can be perpetrated within the limits of the law. The caste Hindu has a legal right to say that he will not employ an untouchable, that he will not sell him anything, that he will evict him from his land, that he will not allow him to take his cattle across his field18.

According to Ambedkar untouchability is seen as an outcome of contradictory forces in society. He points out that, "Untouchability is not a short or temporary feature, it is a permanent one. It is eternal because the religion which has placed untouchables at the lowest rung of the society is itself eternal according to the belief of the Hindus who do not accept any change in the social order."19

Ambedkar strongly pleaded for the annihilation of caste in the speech prepared for the 1936 annual conference of JAT PAT TODAK MANDAL of Lahore. To Ambedkar social revolution was not an easy task. He showed keen interest in abolition of khoti and Watan system of land revenue. He put forth Social equality as major offensive (ideological) against Hindu orthodoxy. The social equality league conducted by Ambedkar and his friends stood for the application of principles of equality in all fields, like religious, political and economical. He upheld the principles of equality and the right to strike and support them the Girini Kamgar Union in April 1929 Bombay textile mill works. Hid independent labour party in 1936 was an attempt to overcome the limits of economism. 


\section{Dr.Pralhad V Chengte}

Ambedkar's exposition of equality and equity is really important because it is very much relevant:

"Equality is not necessarily equity. In order that it may produce equity in society, in order that it may produce justice in society, the different people have to be treated unequally." 20

Right from days of 'Mooknayak' and 'Bahashkrit Bharat' oppression of women remained a major plank of Ambedkar's movement. He involved women in all social struggles. Ambedkar rejects the chaturvarna concept us worth of birth which failed to explain the status and position of women. $\mathrm{He}$ claimed and equal rights for men and women. The Hindu Code Bill embodied sudden basic principles to propagate women's right. The Bill embodied several basic principles of women's rights it sought to abolish different marriage systems prevalent among Hindus and to establish monogamy as the only legal system. It aimed at conferment of right to property and adoption on women. It provided for restitution of conjugal rights and judicial separation. It attempted to unity the Hindu code in tune with progressive and modern thought.

Ambedkar stressed on the need for education and called it the key to progress of mankind. He did not believe in rituals. He action of temple entry movement was to secure civic and human rights has Hindus. The Hindu Code Bill was an attempt to see men and women on equal footing. The Hindu code places women on par with men in matter of property, adoption and marriage. She can now choose her spouse from any caste-high or low- a privilege enjoyed by men only,

I) She has been given absolute right on her property.,

II) Can in her it as mother, sister or daughter in the property of deceased equally with sons,

III) The adopted son cannot deprive her of her share in her husband's property

IV) A girl can also be adopted,

V) For adoption wife's consent is necessary, and

VI) A destitute man can claim maintenance from his more fortune wife.21

Ambedkar as a political revolutionary placed before the Southern -borough committee the demand for "lowering of the fanchise qualification in case of scheduled castes and their election to the state and assembly through communal election"

Aristotle noticed frequent changes in the government of city-states in Greece due to decadence and deterioration in political life which made Aristotle think of revolutions and their consequences. His treatment of it is divided into two parts, part one is a practical manual of conduct advising oligarchs democrats practical manual of conduct advising oligarchs, democrats Aristocrats, monarchs and tyrants as how to keep them in power. In his treatment of revolutions Aristotle discards Plato's priori method and deals with the subject historically and empirically. Aristotle provides the sources of revolution as:

I) The temper of those who make it,

II) The motive from which a revolution is made and

III) The causes and occasions of a revolution.22

He terms most general cause of revolution as an expression of equality and honour by avoiding loses and dishonour and inequality-absolute and proportionate. The most important cause of revolution is the discrepancy between the actual political power and the actual political merit of the different sections of population. He provides particulars causes for revolution as:

I) Love of gain

II) Love of honour

III) Insolence

IV) Fear

V) Undue prominence of individuals

VI) Contempt

VII) Disproportionate increase in some part of the state 
VIII) Election intrigues

IX) Carelessness shown in granting public offices to disloyal citizens

X) Neglect of small changes which might assume large proportions later on, and

XI) Discordance of elements in the state.23

Aristotle continues that even immigration of foreign races could lead to the deterioration of law and order in the state. Aristotle (polity) has mal mixture of oligarchic and democratic elements. He too suggests preventives to revolutions as follows:

i) Too much political power should not be allowed to concentrate in the hands of one man or one class of men.

ii) The various classes in the state are treated with consideration.

iii) Inequalities of offices and honours more than those of wealth drive men to rebellion. Therefore honours and rewards should be distributed as widely as possible. No man or class of men should feel that attainment of political offices or power is impossible of attainment. Political office's should be within the reach of every one capable of performing his duties well. The smaller offices should be given on a long tenure and the higher ones on a short tenure, for a man raised to disproportionate height for a long time likely to become corrupt and tyrannical. It should be impossible for an unknown outsider to seize, suddenly, an office of great political importance. Strangers should not be, ordinarily, given offices. No class of citizens should hold a monopoly of political power.

iv) The government of the state should be so organized that the holder of political power are not able to make money out of their offices. Bribes and other kinds of illegal gratification should be made impossible.

v) A government would gain popularity and, therefore political stability if it so arranges things that the internal details of the administration, particularly the administration of public finances, are open to public scrutiny.

vi) The citizens should be properly educated in the spirit of the constitution of the state. A system of education suited to the constitution is the best of all preservatives of the state.

vii) Stability in the state can be gained by maintaining proportionate equality that is by giving to each his due.

viii) In oligarchies or democracies, the ruling minority or majority should be given equality or even preference in all public offices, save the highest. The highest offices in the state should be awarded solely on considerations of administrative capacity, integrity of character and loyalty to the constitution. In democracies the property of the rich and in oligarchies the rights and dignity of the poor should be respected.

ix) Oligarchies and aristocracies should not allow themselves to be converted to democracies by gradually relaxing democratic spirit must not be pushed too far. The mean must be sought. Polity is Aristotle's panacea against revolutions. No constitution will endure which is not based on popular will.

x) The tyrant must chop off the inconvenient tall poppies. He must employ spies, especially female spies, foment quarrels, and keep people busy and poor. He must show zeal in religion but with dignity and reserve. He must show favours personally but punish through others.

xi) The government should keep before the public danger of foreign attack and should, if necessary, invent dangers to alarm them into being quiet.

xii) A thorough-going realist that he was, Aristotle put the security of the state above everything else. He even permitted interference in the privacy of individual's life when necessary in the interests of the state. If marriages and friendships could lead to revolutions, should they not be regulated by the state. 24

Revolution is a universal phenomenon with wide connotations. It highlights popular discontent with an exploitative operating system or institution. The revolution of Sharana's did succeeded in paving the road towards social change and personality development. 


\section{REFERENCES}

[1] J.C. Johari, "Contemporary Political Theory", Sterling Publication Private Ltd. New Delhi, 1995, p. 419.

[2] Ellul; Autopsy of Revolution, Translated from Fresh Into English by Patricia Wolf (New York; Alfred A Knopt, 1971) p. 101.

[3] Ibid, p. 102.

[4] Ibid, p. 105.

[5] Arendt, "On Revolution" (New York, 1965), p. 21.

[6] J.C. Johari, op. cit., p. 423.

[7] A.S. Cohan: "Theories of Revolution: An Introduction" (London: Nelson, 1975), p. 31.

[8] Ibid, p. 113.

[9] J.C. Johari, op. cit., p. 421.

[10] Ibid, p. 421.

[11] Veerinder Grover., Political thinkers of Modern Indian “Jayaprakash, Narayan”. Deep and Deep Publication, New Delhi - 1990. P. 132.

[12] Ibid, p. 133.

[13] Ibid, p. 184.

[14] Ibid, p. 193.

[15] V.T. Patil "New Dimensions and Perspectives in Gandhism" Inter - India Publications, New Delhi, 1989, p. 138.

[16] Subrata Mukherjee and Sushimita Ramaswamy, "Great Western Political thinkers "Roussean" Deep and Deep Publication, New Delhi, 1993, p. 425.

[17] Thomas, Mathew, “Ambedkar Reform or Revolutionary Segment Book Distributor, New Delhi, 1991, p. 23.

[18] Ibid, p. 25-26.

[19] Dr. Babasaheb Ambedkar Writings and Speeches. Vol. 5, Govt. of Maharashtra, Bombay, p. 21.

[20] Thomas Mathew, op. cit. p. 62.

[21] Dr. Baisantry, "Ambedkar the Total Revolutionary" Segment Book Distributor, New Delhi, 1991, p. 84.

[22] D.R. Bhandari and R.R. Sethi "Studies in Plato and Aristotle" S. Chand and Company (Pvt.) Ltd. New Delhi, 1987, p. 200.

[23] Ibid, p. 201.

[24] Ibid, PP. 201-204. 